\title{
OVERVÅGNINGSNARRATIONER OVERVÅGNING SOM FIGUR OG FORMGREB I SAMTIDSROMANEN
}

Ideen om overvågning har traditionelt været knyttet til synssansen. Fra Guds alvidende øje over Benthams panoptikon-arkitektur til CCTV-kameraerne på togstationerne er det synet, der dominerer. Selv når det er aflytning eller dataovervågning, vi har med at gøre, taler vi ofte om overvågning som en "synliggørelse" af noget ellers "usynligt". Det er derfor ikke overraskende, at diskussionen af overvågningssamfundets samtidskulturelle aftryk i høj grad finder sted i de visuelle medier, som benytter sig af de samme teknologier (kameraer, skærme) som overvågningsindustrien og dermed synes oplagte medier for en undersøgelse af overvågningen som repræsentationsform. Ikke desto mindre stammer vores forestillinger om implikationerne af et overvågningssamfund i høj grad fra litteraturen. Det er således begreber og universer fra så forskellige forfatterskaber som Franz Kafka, Aldous Huxley, George Orwell og Philip K. Dick, der stadig i dag dominerer såvel den samfundsvidenskabelige diskurs som den offentlige debat (eksempelvis "Big Brother"). En forståelse af overvågningens kulturelle og æstetiske aftryk må derfor tage den kulturelle arv fra litteraturen med i betragtning.

I denne artikel skal der argumenteres for, at også samtidslitteraturen tilbyder en refleksion over livsvilkårene i et overvågningssamfund, idet den formår at artikulere en række aktuelle teoretiske og samfundsmæssige problemstillinger på et tidspunkt, hvor overvågning i stigende grad er ikke blot visuel, men ofte data-genereret. I kraft af en række nedslag i værker fra det 21. århundrede, Ulrich Peltzers Teil der Lösung (2007), Catherine O'Flynns What Was Lost (2007) og Tim Lotts The Seymour Tapes (2005), udforskes overvågningens funktion i samtidslitteraturen. En sådan undersøgelse peger på, at overvågning, udover at være en tematisk figur, der artikulerer samtidige livsvilkår, ofte ligeledes fungerer som et fortællemæssigt formgreb, der bruges til at artikulere en meta-refleksion over samtidige repræsentationsvilkår.

\section{Overload \& opmerksomhed}

Forholdet mellem overvågning og fortælling kan forstås bedre, hvis vi tager udgangspunkt i overvågningens og fortællingens fælles interesse for indsamling og repræsentation af information og ser nærmere på den måde, de begge håndterer det, der ofte henvises til som "informationsoverload”. Den mængde af information, 
vi dagligt møder, er øget betragteligt over de seneste årtier, ikke mindst som følge af den teknologiske udvikling, der har ført til betydelige ændringer i mulighederne for at få adgang til, opbevare og kommunikere information. Dette er en udfordring, som både narrativ fiktion og overvågningsteknikker forholder sig til: Romangenren må finde sig til rette i forhold til den øgede mængde af information, som er tilgængelig i hverdagen, hvis den ønsker at reflektere menneskets livsbetingelser i det 21. århundrede. Det kan den gøre enten ved at indoptage overloadet i sin fortælleform og i en vis forstand overloade sin læser med information - eller den kan vælge at udstille sine selektionskrav og skabe bevidst stramt komponerede fortællinger. ${ }^{1}$ Tilsvarende handler overvågning i dag i høj grad om at adskille relevant fra irrelevant information - gigabyte på gigabyte af datamateriale eller CCTV-optagelser er til ingen nytte, hvis vi ikke ved, hvad vi kigger efter. Selektionskriterier er derfor uhyre vigtige og et af de mest omdiskuterede og problematiske områder inden for overvågningsstudier, fordi de nødvendigvis medfører en vis grad af (stereo)typificering. Overvågningstematikken problematiserer således nogle af de udfordringer i forhold til repræsentation, som samtidslitteraturen - og ikke mindst romangenren - står over for i dag, og det er derfor særlig interessant at se på romaner, som direkte beskæftiger sig med overvågning.

I Ulrich Peltzers roman Teil der Lösung er det netop overloadsproblematikken og spørgsmålet om opmærksomhed og overvågning, der står centralt. Romanen udspiller sig i Berlin i begyndelsen af det 21.århundrede. Her er forfatteren og freelanceskribenten Christian på jagt efter en historie om tidligere medlemmer af den Røde Brigade. Samtidig forelsker han sig i den rebelske studerende Nele, der er en del af aktivistmiljøet. Afgørende for romanens skildring af vilkårene for og implikationerne af politisk aktivisme er karakteristikken af samtiden som et kamera-medieret overvågningssamfund. Romanen er fyldt med personer, der tager billeder, og på stationerne og i shoppingcentrene snurrer kameraerne:

"Mod bankens indgang var der rettet videokameraer fra begge sider, videokameraer i en vis højde på hushjørnerne, overvågningsterritorium uden blinde vinkler, ubemærkede felter. Som foran togstationen, hvor hele området med springvand og verdensur med garanti blev optaget dag og nat, elektromagnetisk Panoptikon” (Peltzer: 364). ${ }^{2}$

Den verden, der karakteriseres, er på den ene side tilsyneladende fuldstændig kortlagt af kameraer og uden "blinde vinkler". På den anden side gør romanen os opmærksom på, at denne panoptikontilstand genererer nye felter, der falder uden for synsfeltet - fordi personerne simpelthen ikke formår at identificere den betydningsbærende information. Det ser vi f.eks. i portrætteringen af efterretningstjenestens udfordringer i forhold til at mediere mellem nyttig information og "hvid støj” i

1 For så vidt en klassisk udfordring for romangenren, hvis vigtighed er accentueret i dag.

2 Alle citater i denne artikel er oversat til dansk af artiklens forfatter. 
deres jagt på aktivisterne, men også i de dele af romanen, der handler om forholdet mellem Nele og Christian. Udviklingen af deres kærlighedsforhold fokuserer nemlig i høj grad på den usikkerhed og tolkning af selv de mindste tegn, som kendetegner de første stadier af et kærlighedsforhold. Der sættes yderligere trumf på denne hyperaktive tolkningspraksis, i og med at Christian i størstedelen af romanen er uvidende om Neles aktivistaktiviteter, fordi de tegn, han trods alt får, ikke er dem, han helliger sin opmærksomhed - eller han læser dem i en forkert kontekst. Men overloadsproblematikken kommer måske allertydeligst frem i sidehistorien om Christians ven, den depressive Martin, som lever i paranoid overbevisning om, at han bliver aflyttet og overvåget, og som gentagne gange henvender sig til Christian, inden han vælger selvmordet som udvej. Hans efterladte befinder sig således i en situation, hvor de må indse, at de overså tegnene på hans desperation - eller valgte at fokusere deres opmærksomhed andetsteds.

I dens karakteristik af samtidens overvågningssamfund peger romanen således på opmarksombed som en central term. Hermed placerer den sig i forlængelse af Großstadts-romanen og en moderne problematisering af opmærksomhed og perception. ${ }^{3}$ Men snarere end storbyens sansebombardement er det her datamængden $\mathrm{i}$ et digitaliseret informationssamfund, der er udfordringen. I åbningskapitlet, der skildrer en aktivist-happening rettet mod overvågningskameraerne i Sony Centeret på Potsdamer Platz i Berlin ${ }^{4}$, set fra sikkerhedsvagternes synspunkt, får vi en karakteristik af overvågning og informationsstrøm som perceptionsvilkår:

"Man bliver en del af det - en slags automatik, som punktligt indtræeder med arbejdsdagens begyndelse, når døren åbnes og blikket falder på skærmen, som man ikke taber af syne resten af dagen. At akkumulere viden, det man kalder erfaring, øvelse i meditativ erkendelse” (Peltzer: 9).

Romanen som helhed illustrerer, at denne meditative erkendelsesform ikke blot er gældende for sikkerhedsvagter, men skal ses som et generelt vilkår for perception og erkendelse. En karakteristik, som vi også finder hos arkitekturhistorikeren Beatriz Colomina:

"Vi er i dag overalt, hele tiden omgivet af et opbud af mange forskellige billeder. På gaden, i lufthavne, shoppingcentre og fitnesscentre, men også på vores computere og i fjernsynet. Ideen om et enkelt billede, som behersker vores opmærksomhed, er forsvundet. Det virker, som om vi har behov for at blive distraheret for at kunne koncentrere os" (Colomina: 323).

3 Se f.eks. Jonathan Crary.

4 Potsdamer Platz er i denne forbindelse et betydningsbærende sted, idet området har bevæget sig fra at være indbegrebet af koldkrigstidens overvågningskultur til at rumme den nok mest karakteristiske moderne overvågningslokation - shoppingcenteret. 
Beskrivelsen af sikkerhedsvagternes arbejde i Teil der Lösung giver et meget konkret billede af en sådan tilstand, hvor koncentrationen opstår i et meditativt mode, der ligger et niveau under, hvad vi normalt betegner som bevidst opmærksomhed. Fokus bliver en slags automatik, der dog hele tiden er klar til at bemærke det usædvanlige: "en irritation som et lyn, der pludselig fanger opmærksomheden, en impuls af fare, der kommer ud af intet og elektrificerer ånden” (Peltzer: 10). Det er en tilstand af konstant vagtberedskab - af på samme tid enorm koncentration og meditativ distraktion - som ikke lader plads til anden tankevirksomhed.

I kraft af Christians refleksioner over sin skriveproces, som netop synes præget af denne tilstand af meditativ koncentration, kobles romanens karakteristik af opmærksomhedens vilkår til konstruktionen af narrative strukturer:

"Hvordan skriver man i et stormløb af billeder, som intet har at gøre med handlingen, med planen på væggen, de sidste linjer i den åbne fil? (En stiknarkoman renser tænder med en skruetrækker ved Kottbusser Tor. Overhørte dialogbidder, tilfældige observationer.)" (Peltzer: 304).

Christians litterære ambition er at opløse subjektet som fortællerstemme og lade det erstatte af en "anonym mumlen" (Peltzer: 131): "Det drejer sig om stemmer, stemmer fra alle områder, fra oven, fra neden, som i skiftende tonelejer ville kunne skitsere et hverdagspanorama, dagligdagen i alle dens facetter" (Peltzer: 260). I romanens univers skabes der således paralleller mellem overvågningens og romanskrivningens udfordringer, som peger tilbage på Teil der Lösungs eget repræsentationsprojekt og den læseroplevelse, den genererer. Teil der Lösung bygger langsomt en spænding op i kraft af sine mange handlingstråde og karakterer og udfordrer dermed sin læser til at sortere relevant fra irrelevant information og identificere kausalsammenhænge, der giver mening. Fortælleformen er filmisk - iagttagende og observerende uden en engageret og vurderende fortællerstemme, uanset om vi følger aktivister eller politi - men der er mange og dramatiske klip mellem de forskellige historier og karakterer. Det er altså kameraets optik, vi har med at gøre, i mere end én forstand. Romanen medierer således mellem overvågningskameraets uredigerede registrering og filmkameraets bevidste komposition - mellem overload og nøje overvejet selektion - og formidler dermed sin refleksion over opmærksomhedens vilkår i et overloadet overvågningssamfund, ikke bare i en række tematiske modulationer, men også i selve den måde, hvorpå romanen fortæller sin historie.

\section{Ubemarket overvågning i kontrolsamfundet}

Koblingen af overload og overvågning er signifikant og kan ligeledes spores i filmnarrationer såsom Michael Hanekes Caché (2005). Den kan imidlertid antage mange former. I Catherine O'Flynns What Was Lost ser vi en anden type narrativ respons på overloadsituationer genereret af overvågning - én, der ikke går ud på at mime overloadet, men derimod at reducere det. Øvelsen går ud på at gøre overvågningen 
ubemarket, og den mestres af den tiårige Kate, der er fortæller i den første del af romanen, som foregår i 1984. Hun er en egensindig og ensom pige, der har mistet begge sine forældre og nu bor hos sin bedstemor, hvor hun bruger det meste af sin tid på at lege detektiv og holde nabolaget - især det nærliggende shoppingcenter Green Oaks - under observation. Hun noterer systematisk sine iagttagelser i en lille notesbog, og som læser forvirres man indledningsvis af disse mange optegnelser og føler (som Kate selv) en usikkerhed omkring, hvilke begivenheder der er vigtige. Det er dog ikke dette indledningsvise overload, der er det centrale i romanens behandling af overvågning. Det er derimod Kates evne til ikke at blive bemærket, når hun observerer verden:

"Hun havde fået fornemmelsen af, at voksne ikke brød sig om hendes ture på egen hånd, så når hun nu om dage blev udspurgt af en butiksassistent, sikkerhedsvagt eller en forælder, plejede hun at antyde, at et uspecificeret, voksent familiemedlem bare lige var henne $i$ en anden forretning. I det store hele var der dog ingen, der udspurgte hende, rent faktisk lagde ingen rigtig mærke til hende. Undertiden troede Kate, at hun var usynlig" (O’Flynn: 5).

Vi er hermed tilbage ved karakteristikken af overvågningens indflydelse på opmærksomheden, som blev anslået med karakteristikken af den meditative koncentration i Teil der Lösung. I What Was Lost er fokus dog ikke primært på overvågernes bevidsthedsniveau, men i lige så høj grad på omgivelsernes opmærksomhed på, at de bliver overvåget. Til trods for Kates intensive deltagelse som observatør af lokalmiljøet er hendes personlige relationer minimale. Hendes usynlighed er således et gennemgående eksistensvilkår, men det er også en evne, som hun opøver og dyrker i sin selvudnævnte egenskab af detektiv. Kate bliver på den måde en personifikation af en tilsyneladende uskyldig form for overvågning, som er båret af ønsket om at forstå andre mennesker og deres handlemønstre og i sidste ende at kunne vinde de voksnes anerkendelse og opmærksomhed. En ubemærket overvågningsform, som næres af ønsket om synlighed og menneskelig kontakt.

Spørgsmålet om synligheden af den overvågning, vi er objekt for, er interessant i et teknologisk og samfundsmæssigt perspektiv. Hvis overvågningsteknologier skal fungere optimalt, skal de helst formå at sortere informationsmængderne i al ubemærkethed og kun pådrage sig opmærksomhed i særlige tilfælde. De skal med en term fra informationsteoretikeren Mark Weiser - være "calm". Weiser præsenterede i 1990'erne visionen om at imødegå informationssamfundets overload ved hjælp af teknologier, der er så integrerede i vores dagligdag, at vi ikke længere bemærker dem - allestedsnærværende "calm technology" (Weiser \& Brown). Teknologisk "calmness" synes at være en nødvendighed i et samfund, hvor teknologi gennemsyrer vores kroppe og omgivelser og er indlejrede i selv de mest dagligdags erfaringer - fra sensorerne, der tænder lyset på offentlige toiletter, til kattelemmen, der aflæser chippen i Missers nakke og holder uønskede katte ude af huset. Hvis sådan et samfund skal fungere, er det en nødvendighed, at teknologien arbejder 
ubemærket uden at tiltrække sig opmærksomhed for ikke at gøre det kognitive overload uhåndterligt. Den distræte koncentration, vi så hos Peltzer, er altså her yderligere automatiseret. Samtidig er det imidlertid uhyre vigtigt at holde sig for øje, hvilke mekanismer i samfundet og i vores omgang med verden, som hermed forvises til et niveau under vores bevidste opmærksomhed. Et eksempel på overvågning, som er så indlejret i vores dagligdag, at vi ikke længere tildeler den vores bevidste, reflekterede opmærksomhed, men lader den foregå ubemærket i baggrunden af vores liv, er såkaldt "facial recognition software", der identificerer en person ved at sammenligne udvalgte ansigtstræk fra et digitalt billede med en database. En teknologi, som er hyppigt brugt i sikkerhedssystemer i lufthavne, men også hos sikkerhedsfirmaer i private virksomheder eller i storcentre. Andre former for ubemærket overvågning finder vi i den form for "profiling", der finder sted i telefonkøsystemer eller på kommercielle hjemmesider, som differentierer priser og serviceniveau i forhold til forskellige kundegrupper. Til trods for at teknologien fungerer ubemærket, og overloadssituationen både skabes og håndteres af systemet, uden at den behøver komme til vores kendskab, har den således stor indflydelse på vores liv og samfundsstrukturer. ${ }^{5}$

Disse teknologiserede dimensioner af overvågning reflekteres i anden del af What Was Lost, hvor vi 20 år senere følger den butiksansatte Lisa og sikkerhedsvagten Kurts forsøg på at opklare, hvorfor Kate forsvandt. Lisa og Kurt arbejder begge i Green Oaks shoppingcenter. Et miljø, der i 2003 beskrives som domineret af overvågning $i$ alle afskygninger:

"Rækkerne af sikkerhedsvagter i centret var udvidet med de vagter og butiksdetektiver, som de fleste forretninger ansatte internt, hvilket blev til omkring to hundrede sikkerhedsvagter, som arbejdede på Green Oaks fire kvadratkilometer. Vagter, forfølgere, tjenere, folk, der var mistænksomme, folk, der kedede sig, på udkig efter tegn, på udkig efter ballade” (O’Flynn: 84).

Den uskyldige observatør, vi mødte i form af Kate, er erstattet af overvågningsformer, som er langt mere synlige og foruroligende for dem, der overvåges: "Lisa blev mere og mere sikker på, at hun blev overvåget; hun følte sig synlig på en skræmmende måde. Nogen overvågede, men de kom hende ikke til hjælp. Hun blev observeret og vurderet" (O’Flynn: 121). Det, der især er interessant i karakteristikken af oplevelsen af at blive overvåget i denne del af romanen, er, at ensomheden og manglen på tætte menneskelige relationer, ligesom i Kate-delen af fortællingen, kobles til overvågning, som også for Lisa og Kurt fremstilles som et eksistensvilkår - en uomgængelig del af deres dagligdag i konsumsamfundet. Den verden, vi får indblik i, er gennemsyret af software-sortering - som f.eks. når elevatoren i storcentret automatisk prioriterer kundernes etagevalg over de ansattes adgang til lageretagerne. På sin vis glider alt let og uproblematisk - her er ikke stor risiko for

5 Wood \& Graham bruger termen "software-sorted societies". 
overload - det, der karakteriserer såvel Lisas som Kurts liv, er inerti og manglen på noget, der kan forstyrre det velfungerende nærmest autopoietiske system, hvor alle er kontrolleret, men ingen har kontrol. ${ }^{6}$

Denne kobling af overvågning og kontrol får sit mest perverterede udtryk hos Kurts kollega, Gavin, som viser sig at være skyld i Kates død:

"Når du betragter nogen, har du ingen kontrol over, hvor de går hen. De kan gøre, hvad de vil, og alt, hvad du kan gøre, er at stå i skyggen og se på. Det er en følelse af magtesløshed. Men når nogen betragter dig, har du kontrollen” (O’Flynn: 236).

Den afmagtssituation, som det lukkede overvågningssystem afføder (og som hensætter Lisa og Kurt i en apatisk utilfredshed med deres liv), bevirker, at Gavin vender magtforholdet i overvågningssituationen på hovedet og konkluderer, at eftersom hans egen position som overvåger ikke giver ham en følelse af kontrol, må kontrollen ligge hos den, der overvåges. Romanen som helhed viser imidlertid, at magtesløsheden er lige stor hos de overvågede som hos overvågerne. Den distancerede observation kan ikke erstatte meningsfulde menneskelige relationer, men kun føre til inerti, ensomhed og tab.

Mens Peltzers overloadsroman efterlod os med en mængde løse tråde, hæfter What Was Lost i langt højere grad en ende og etablerer et hierarki for vigtigheden af de informationer, vi får. Ligesom det klaustrofobiske overvågningsunivers i shoppingcenteret, lukker romanen sig fortælleteknisk om sig selv, og kun i Lisa og Kurts begyndende romance finder vi en handlingstråd, der peger ind i fremtiden. De synes at være de eneste karakterer, der rummer muligheden for at bryde ud af det lukkede betragter-betragtet system og erstatte den afstandstagende observation med en meningsfuld relation. Kate og Gavin er derimod begge fanget i deres roller som observatører, hvis ønske det er selv at blive bemærket. Til trods for, at vi i både Teil der Lösung og i What Was Lost befinder os i det kamera-overvågede shoppingcenter, har overvågning andre konnotationer og dermed også andre tematiske og formmæssige konsekvenser i What Was Lost. Her bliver overvågningens karakter af almen menneskelig kvalitet (jf. betydningen af det franske "surveiller" at våge over nogen) vendt på vrangen og gjort til et spørgsmål om ubemærkethed og ensomhed som menneskelige eksistensvilkår. Med andre ord er det i denne roman ikke overvågningen, men mennesket, der bliver usynligt, jo mere overvågning integreres i vores dagligdag.

\section{Reprosentationens mulighedsbetingelser}

Indtil nu har vi set, hvorledes koblingen af overvågning og narration sætter fokus på informationsoverload som et markant træk ved samtiden, og vi har iagttaget to forskellige narrative strategier i forhold til denne overload - hos Peltzer omfavnes

6 Det er Deleuzes kontrolsamfund, vi har med at gøre: "Vi beskæftiger os ikke længere med masse over for individ. Individer er blevet til "dividuelle" og masserne til stikprøver, data, markeder eller 'banker"” (5). 
den og bliver til en del af den narrative struktur, mens den hos O'Flynn udhules og vakuumpakkes til en stram komposition. Det fører os frem til spørgsmålet om overvågningens krav på referentialitet - dens forhold til virkelighedsgengivelse. Kulturteoretikeren Thomas Levin argumenterer i sin artikel "Rhetoric of the Temporal Index: Surveillant Narration and the Cinema of 'Real Time" for, at der inden for film er sket en bevægelse fra en tematisk interesse for overvågning (som f.eks. Fritz Langs Dr. Mabuse film og Hitchcocks Rear Window) til en mere strukturel tilgang til overvågning som selve mulighedsbetingelsen for fortællingen. Han placerer én af bevæggrundene for denne udvikling i det skift, som det digitale billede har bevirket i forhold til vores tiltro til fotografiets referentialitet, idet mulighederne for manipulation med det digitale fotografi udstiller billedets karakter af konstruktion. Levin argumenterer for, at overvågningsbilledet, som transmitteres i "real-time", overtager denne realisme-effekt i en række film fra 1990'erne og fremefter, idet en real-time transmission i højere grad undgår mistanke om manipulation i postproduktionen. Inden for litteraturen genfinder vi diskussionen i den opblussen af det selvbiografiske, der præger samtidslitteraturen, og i Tim Lotts The Seymour Tapes kobles det selvbiografiske som litterært greb med overvågningen som tema og bliver udgangspunkt for en udforskning af repræsentationens mulighedsbetingelser. I modsætning til hos Levin er der dog ikke megen tiltro til overvågningskameraets troværdighed, i stedet gribes der til en romantradition for utroværdige fortællere.

Fortælleren i The Seymour Tapes er en forfatter ved navn Tim Lott, der hyres til at skrive en bog om lægen Alex Seymours død. Seymours efterladte hustru, Samantha, føler, at forløbet omkring hans død er blevet fremstillet fejlagtigt i medierne og ønsker at give ham oprejsning i form af en posthum dokumentation af forløbet. Men figuren Alex Seymour er en fiktiv karakter, og bogen, han optræder i, en roman, så allerede her er tilliden til den sandfærdige gengivelse undergravet. På handlingsplanet udforsker romanen overvågningskameraets troværdighed som repræsentationsform, idet den fortæller historien om den midaldrende Dr. Seymour, som på grund af mistanke om konens utroskab, truende sagsanlæg mod sin praksis og en generel følelse af utilstrækkelighed i livet og rollen som far installerer skjulte overvågningskameraer i sit hjem og sin praksis. Romanen følger Lotts kortlægning af forløbet, der viser, hvordan Seymours overvågning fører til, at han finder en fortrolig i kvinden Sherry Thomas, som sælger ham overvågningsudstyret. Hun viser sig imidlertid at lide af en nærmest dokumentarisk besættelse og myrder ham for åbent kamera, da han ønsker at trække sig fra overvågningsprojektet. I en sidste dramatisk vending afsløres det, at Seymours mistanke til hustruen faktisk var velbegrundet, og at hun muligvis har en medskyld i mordet.

Vi har således at gøre med en kompleks fortælling, der leger med fiktionens og repræsentationens muligheder og blinde vinkler med overvågningsfiguren som central trope. Fortælleformen veksler mellem transskriptioner af interviews og beskrivelser af CCTV-optagelser. Begge fortællegreb lover en vis form for neutralitet, men er ledsaget af fortællerens kommentarer, der henleder opmærksomheden på den grad af redigering og komposition, som materialet nødvendigvis må undergå 
for at gå fra råt datamateriale til fortælling. Vi er således tilbage ved spørgsmålet om overload, selektion og opmærksomhed, som vi så modelleret i What Was Lost og Teil der Lösung. Fortælleren Lotts strategi er at selektere i det omfangsrige datamateriale, han får overleveret:

"I dette tilfælde har jeg gjort mit bedste for at gøre min beretning af fakta neutral - det er for nylig gået op for mig, at det måske er et underbevidst forsøg på at konkurrere med kameraet om retten til at repræsentere det, vi kalder 'virkelighed', korrekt. De fakta, jeg har udvalgt, de citater, jeg har brugt, de sektioner af videobåndene, som jeg har vurderet irrelevante, kedelige eller for nærgående, er ikke desto mindre alle sammen faktorer, som betyder, at den version af virkeligheden, som jeg har konstrueret, er fortegnet" (Lott: 5).

Lotts ønske om at konkurrere med overvågningskameraets privilegerede fortælleposition ekkoer Levins pointe om, at overvågningsoptagelsen rummer et løfte om realisme, men i romanens sidste kapitel sættes der ligeledes spørgsmålstegn ved troværdigheden af denne form for repræsentation. Her er fortælleren ikke længere Lott, men et "kamera-jeg", der hævder at være til stede, både når Tim Lott er til møde hos sit forlag, når den gravide Samantha mødes med sin elsker, når Alex Seymours søn græder, når datteren afviser moderens opkald, og når læseren læser romanen. Denne fortæller insisterer på at observere uden at fortolke eller læse motivationer ind i de handlinger, der udspiller sig, men kapitlet udstiller snarere den hårfine grænse mellem observation og fortolkning i kraft af fortællerens mislykkede fors $\varnothing g$ på neutralitet - ikke mindst på grund af klippene mellem de forskellige sekvenser, der er ladede med emotionel effekt. Som hos Peltzer er bevægelsen fra datamateriale til meningsfuld information således central, hvilket i The Seymour Tapes bruges til at afmontere ideen om overvågningskameraet som privilegeret, guddommelig synsvinkel - en tematik, som ligeledes udforskes på handlingsplanet.

Seymours ulykkelige skæbne udspringer af hans tro på, at det, kameraet viser, vil kunne give ham vished $i$ forhold til sin kone og et forspring $i$ forhold til børneopdragelse. Hans tillid til kameraets dokumentariske effekt er så at sige for stor. I modsætning til Gavin i What Was Lost, som tog kontrol ved at blive set, føler Seymour sig alvidende og i kontrol ved at bruge kameraet som en udvidelse af hans eget synsfelt. Romanen tematiserer således det guddommelige overmod, der ligger i overvågning - her i en udtalelse fra én af Seymours videodagbøger, hvor han overvejer effekten af overvågningen af sønnen:

"han er ved at lære, at der ikke er nogen årsag uden effekt, at der ikke er nogen overskridelse uden straf, fordi han bliver set, Herre, af sin far, ligesom du, vor Far, våger over os. Han vil måske hade den retfærdighed, som rammer ham som lyn fra en klar himmel nu, men han må have hadet det så meget mere, dengang der ikke var anden retfærdighed, end hvad han kunne slippe af sted med. Nu er der orden. Nu er der struktur. Så nu kan der blive fred” (Lott: 182). 
Overvågningen giver således Seymour en fornemmelse af at blive al-seende og dermed i en vis forstand guddommelig, men romanens Ødipale pointe er, at Seymour langt fra bliver al-vidende. Den dokumenterende overvågning kan ikke erstatte en empatisk indlevelse i familiens dynamik, ligesom vi i What Was Lost så, hvordan den distancerede observation ikke kunne erstatte meningsfulde menneskelige relationer. Seymour indser ikke konens dobbeltspil, og det bliver hans tragedie.

På det formmæssige såvel som det handlingsmæssige plan etableres der således i romanen en parallel mellem repræsentation i form af narration og repræsentation i form af overvågning. Der ligger i både fortællerens og overvågerens rolle en magt, men også et potentielt overmod, fordi de påtager sig at gengive virkeligheden. I og med at de påtager sig selektionen i datamaterialet, åbner de nemlig også muligheden for fejlfortolkninger på det emotionelle plan, som de mange forskellige fortælleformer og synsvinkler i romanen viser.

\section{Samtidslitteratur og overvågning}

Mængden af samtidslitteratur, som beskæftiger sig med overvågning som tematik, er betydelig, ikke mindst inden for science-fiction genren. Ingen af de tre romaner, vi har beskæftiget os med i denne artikel, hører imidlertid til science-fiction genren. Det, vi får skildret, er ikke dystopiske scenarier om fremtidige overvågningssamfund i Orwell, Huxley og Dicks tradition. Integreringen af overvågning i plot og fortællestrukturer i de tre romaner skildrer derimod overvågning som noget, der allerede er en naturlig del af vores livsverden. Overvågning er her ikke kun et udefrakommende fremmedlegeme, men ligeledes dybt integreret i karakteristikken af de emotionelle og menneskelige relationer, hvilket nødvendigvis påvirker overvågningens funktion i fortællingen. Heri ligger der en interessant pointe, som peger på et signifikant træk ved overvågningens position i samtidskulturen. Teknologiske nybrud har tendens til især at markere sig stærkt tematisk i den utopiske og dystopiske litteratur, så længe de udgør en udfordring for den menneskelige perceptionsevne. ${ }^{7}$ Efterhånden som de integreres i vores dagligdag og ikke længere på samme måde udgør en kilde til kognitivt overload, bliver det litterære aftryk mere forskelligartet.

Det er et sted i denne bevægelse, at vi i øjeblikket befinder os, når det kommer til overvågningsteknologi. Overvågning er i dag i høj grad et fænomen, der genererer passionerede standpunkter, og de dystopiske science-fiction fremstillinger er fortsat fremherskende. Men overvågning er også i stigende grad et fænomen, som indgår stadig mere ubemærket i vores dagligdag, og dermed får den i litteraturen i højere grad andre funktioner end den spændingsbærende tematiske. Teil der Lösung, What Was Lost og The Seymour Tapes beskæftiger sig alle eksplicit med overvågning. Imidlertid er det, der er interessant i deres bearbejdning af overvågning, ikke kun analysen eller udsigelsen omkring overvågningens samfundsmæssige implikationer på det konkrete, tematiske plan, men i lige så høj grad den måde, hvorpå overvåg-

7 Et andet eksempel er computerteknologien i anden halvdel af det 20.århundrede. 
ningsproblematikkerne bruges til en refleksion over repræsentationsvilkår i det 21 . århundrede. Hermed peger romanerne på overvågningsteknologiens indflydelse på et æstetisk og mentalhistorisk niveau, der kan sidestilles med den måde, det tidlige 20. århundredes chokæstetik og montageteknik ofte kobles til opkomsten af den moderne storby.

De tre romaner artikulerer koblingen mellem narration og overvågning som figur og formgreb på hver sin måde og sætter herigennem fokus på centrale karakteristika ved samtidens overvågningspraksisser og deres menneskelige implikationer. Her handler det ikke blot om overvågning som et aktuelt fænomen, der kan forstås i et binært modsætningspar mellem "sikkerhed" og "privatliv", og som vi på det samfundsmæssige plan kan forholde os til i form af sikkerhedspolitik og på det personlige plan i indstillingen af vores "privacy-settings” på Facebook. I kraft af romanernes interesse for menneskeskæbner og subjektivitet åbner de for en forståelse af indlejringen af nye overvågningsteknologier i vores dagligdag som del af en kulturhistorisk tradition, f.eks. i forhold til opmærksomhed og perception, men også i relation til de affektive og emotionelle implikationer af overvågning. Med afdækningen af overvågning som ikke blot et tematisk anliggende, men i høj grad også et fænomen, der sætter sig spor i romanernes narrative strukturer, får vi således en tilgang til overvågning, der på et mere fundamentalt plan ser på, hvilken indflydelse den accentuering af overvågningspraksisser, vi i øjeblikket er vidne til, har på vores oplevelse, forståelse og repræsentation af verden.

\section{LITTERATURHENVISNINGER}

Colomina, Beatriz. "Enclosed by Images: Architecture in the Post-Sputnik Age." Ctrl [Space]: Rhetorics of Surveillance from Bentham to Big Brother. Red. Thomas Y. Levin, Ursula Frohne og Peter Weibel. Cambridge, Mass.: MIT Press, 2002: 322-37.

Crary, Jonathan. Suspensions of Perception: Attention, Spectacle and Modern Culture. Cambridge, Mass.: MIT Press, 2001.

Deleuze, Gilles. "Postscript on the Societies of Control.” October 59 (1992): 3-7.

Levin, Thomas Y. "Rhetoric of the Temporal Index: Surveillant Narration and the Cinema Of 'Real Time'." Ctrl [Space]: Rhetorics of Surveillance from Bentham to Big Brother. Red. Thomas Y. Levin, Ursula Frohne og Peter Weibel. Cambridge, Mass.: MIT Press, 2002. 578-94.

Lott, Tim. The Seymour Tapes. London: Penguin, 2006.

O'Flynn, Catherine. What Was Lost. Birmingham: Tindal Street Press, 2008.

Peltzer, Ulrich. Teil Der Lösung. Zürich: Amman Verlag, 2007.

Weiser, Mark, og John Seely Brown. “The Coming Age of Calm Technology.” (1996): 4. maj 2010 <http://nano.xerox.com/hypertext/weiser/acmfuture2endnote.htm>.

Wood, David Murakami, og Stephen Graham. "Permeable Boundaries in the Software-Sorted Society." Mobile Technologies of the City. Red. Mimi Sheller and John Urry. London, NY: Routledge, 2006: 177-91. 